\title{
Academic Trajectories of Dental Researchers Receiving CNPq's Productivity Grants
}

\author{
Ana Carolina SCARPELLI \\ Fernanda SARDENBERG \\ Daniela GOURSAND \\ Saul Martins PAIVA \\ Isabela Almeida PORDEUS \\ Department of Pediatric Dentistry and Orthodontics, Dental School, \\ Federal University of Minas Gerais, Belo Horizonte, MG, Brazil
}

\begin{abstract}
The present study analyzed the profile of dental researchers receiving grants related to their productivity in research from the Brazilian National Research and Development Council (CNPq). Data collection was carried out in March 2008, using the Brazilian database for curriculum vitae (Lattes Format). There were 144 researchers registered in the database and linked to 25 institutions. These researchers published a total of 12,997 full-text articles, 6,927 of which were published in the last 5 years. Category 1 grant holders $(\mathrm{n}=77)$ were responsible for $53.5 \%$ of this production; Category 2 grant holders $(n=65)$ were responsible for $45.1 \%$; Senior grant holders $(n=2)$ were responsible for $1.4 \%$. Regarding institutional affiliation, $90.3 \%$ of the research grants holders develop activities at public institutions and $9.7 \%$ develop activities in private institutions. Furthermore, $84.0 \%$ of the researchers are linked to institutions located in the southeast region of Brazil and $75.0 \%$ of the researchers perform their activities in the state of São Paulo. This study performed a mapping of the distribution of CNPq researchers, revealing a concentration in the southeast region of the country, especially in the state of São Paulo. The findings of the present study also demonstrate the important contribution of grant holders to the scientific production in dentistry in Brazil.
\end{abstract}

Key Words: research, research personnel, research support, dental research, bibliometrics.

\section{INTRODUCTION}

Changes in the organization of the historic western model of the State have been observed, with a clear tendency toward a reduction in direct economic and social activities. There has also been a broadening in some of the roles of the State with regard to designing policies and regulations that address diverse parameters of social life. As a result, it is well accepted that scientific knowledge is essential to the foundation of the decisionmaking process (1).

Knowledge is also used to organize healthcare activities. Contemporary society recognizes that science, technology and innovation are differentiating factors in the social and economic development of countries and regions. Thus, science and technology in the healthcare field are the objects of different governmental and academic initiatives (2).

In Brazil, as well as in other Latin American countries, there was a considerable increase in investments in science in the 1970s and 1980s (3). Moreover, scientometric studies have recorded a significant growth in Brazilian scientific production in recent decades. The establishment of postgraduate courses in the second half of the 1960s marked the beginning of the formation of a vigorous scientific community in the country. In the last 15 years, Brazil has seen an expressive increase in scientific production, as measured by the number of scientific articles published in international dental journals. Brazilian production currently indexed in the Web of Science database approaches $1.5 \%$ of the world's scientific production. 
This participation was $0.5 \%$ two decades ago $(4,5)$.

Considering the scientific performance exhibited in the last 40 years of more expressive activities in Science and Technology in Brazil, greater production efforts have been observed in fields that are more qualified in human resources, namely, physics, medicine (and its sub-fields, including dentistry), biomedical sciences (biochemistry, biophysics, microbiology, pharmacology, neuroscience, cell biology, developmental biology, physiology and immunology) and chemistry. Together, these fields account for $70 \%$ of national scientific production (6). According to Cury (7), based on the ISI Web of Science, listing address, article, 'Dent*', 'Brazil*', the number of papers published between 2001 and $2003(\mathrm{n}=898)$ was similar to that of the entire past century $(\mathrm{n}=854)$. The asterisk $(*)$ means that the search was made from the root of the word.

The Brazilian National Research and Development Council (CNPq) is an agency linked to the Ministry of Science and Technology. Investments from this agency are directed toward the formation and absorption of human resources. The aim is to finance research projects that contribute to the production of scientific knowledge and the generation of new opportunities of growth for the country (8). The 'Productivity in Research' grant is an 'Individual grant' modality whose purpose is to distinguish outstanding Brazilian researchers, valuing their scientific production according to the criteria established by the $\mathrm{CNPq}$ and its Advisory Committees. Therefore, this grant represents a constant stimulus to Brazilian researchers (9).

The increase in Brazilian dental scientific production is demonstrated by the growing number of articles by researchers affiliated to Brazilian universities that are published in both national and international journals in order to make public scientific findings and disseminate knowledge in the field of Dentistry (10).

The aim of the present study was to determine the profile and distribution of researchers in Dentistry who receive productivity $\mathrm{CNPq}$ grants.

\section{MATERIAL AND METHODS}

A list of dental researchers with active productivity grants was obtained from the $\mathrm{CNPq}$ website (www.cnpq.br) in March 2008, following the criteria established by the CNPq Directive Body. Research grant holders in the field of Dentistry are selected based on their scientific productivity over the last 5 years.

The curricula vitae of all researchers for each of the categories and sublevels $(2,1 \mathrm{D}, 1 \mathrm{C}, 1 \mathrm{~B}, 1 \mathrm{~A}, \mathrm{SR})$ were analyzed. The classification of researchers is based on criteria such as technical-scientific production, participation in the formation of human resources and specific performance in each field of the science. The analysis of curricula vitae was carried out using the Lattes Format (available at www.cnpq.br), which consists of a database of curricula vitae and institutions of science and technology, developed for CNPq and used as a curriculum vitae information system by the Ministry of Science and Technology (MCT), the Financing Body for Studies and Projects (FINEP), the Coordination of Higher Education Personnel Improvement (CAPES) as well as all institutional agents and the Brazilian scientific community.

Databases containing information of gender, institutional affiliation of the research grant holders and scientific production were constructed. Scientific production was based on the production of full articles in national and international scientific journals referring to the entire period of the researcher's academic activity. Data were analyzed using the Statistical Package for the Social Sciences (SPSS; version 15.0; SPSS Inc. Chicago, IL, USA) and Microsoft Excel software.

\section{RESULTS}

There were a total of 144 researchers in Dentistry with $\mathrm{CNPq}$ productivity grants. The group of researchers was formed by 93 men $(64.6 \%)$ and 51 women $(35.4 \%)$, revealing the predominance of the male gender. Furthermore, men were concentrated in Category $1(58.0 \%)$ and women were concentrated in Category $2(52.9 \%)$ (Table 1$)$.

The analysis of scientific production revealed that 12,997 full-text articles were published in national and international journals, 6,927 of which were published in the last 5 years. Category 1 grant holders were responsible for $53.5 \%$ of this production, whereas Category 2 grant holders were responsible for $45.1 \%$ and senior grant holders were responsible for $1.4 \%$.

Significant differences in the average number of full-text articles published per researcher in each category and sublevel were observed (Table 2).

Considering the institutional affiliation, the research grant holders pertained to 25 institutions. A total 
of $130(90.3 \%)$ developed their activities at public institutions, whereas $14(9.7 \%)$ developed their activities at private institutions. It was also observed that 121 $(84.0 \%)$ researchers were affiliated with institutions located in the southeast region of Brazil and 108 (75.0\%) of all researchers developed their activities in the state of São Paulo (Table 3).

\section{DISCUSSION}

The performance of Brazilian science is related to the formation of human resources in Science and

Table 1. Distribution of CNPq grant holders in productivity in dentistry according to gender and category/sublevel.

\begin{tabular}{crrr}
\hline \multirow{2}{*}{ Category/Sublevel } & \multicolumn{2}{c}{ Gender } & \multirow{2}{*}{ Total (100\%) } \\
\cline { 2 - 3 } & \multicolumn{2}{c}{$\begin{array}{c}\text { Male } \\
\mathrm{n}(\%)\end{array}$} & $\begin{array}{c}\text { Female } \\
\mathrm{n}(\%)\end{array}$ \\
\hline 1A & $11(73.3)$ & $4(26.7)$ & 15 \\
1B & $17(81.0)$ & $4(19.0)$ & 21 \\
1C & $12(60.0)$ & $8(40.0)$ & 20 \\
1D & $14(66.7)$ & $7(33.3)$ & 21 \\
2 & $38(58.5)$ & $27(41.5)$ & 65 \\
SR & $1(50.0)$ & $1(50.0)$ & 2 \\
Total & $93(64.6)$ & $51(35.4)$ & 144 \\
\hline
\end{tabular}

Source: Lattes Format - March 2008.

Table 2. Distribution of scientific articles published by CNPq productivity grant holders in dentistry according to category/ sublevel (2003-2008).

\begin{tabular}{cccc}
\hline $\begin{array}{l}\text { Category } \\
\text { /Sublevel }\end{array}$ & $\begin{array}{c}\text { Total production } \\
\text { in the last 5 years } \\
(\mathrm{n}=6,927)\end{array}$ & $\begin{array}{c}\text { Production } \\
\text { per researcher } \\
\text { (number of articles) }\end{array}$ \\
\cline { 2 - 3 } & $\mathrm{n}(\%)$ & $\%$ accumul. & \\
\hline \multicolumn{1}{c}{ 1A } & $1,116(16.1)$ & 16.1 & 74.4 \\
1B & $1,006(14.5)$ & 30.6 & 47.9 \\
1C & $1,129(16.3)$ & 46.9 & 56.5 \\
1D & $962(13.9)$ & 60.8 & 45.8 \\
2 & $2,629(38.0)$ & 98.8 & 40.4 \\
SR & $85(1.2)$ & 100.0 & 42.5 \\
\hline
\end{tabular}

Source: Lattes Format - March 2008.
Technology, centered on the recognized success of postgraduate courses that began in the late 1960s. Despite the relatively young age of the Brazilian educational and scientific system, scientific production has grown considerably in all fields of knowledge in recent decades. There has also been an increase in the number of citations of Brazilian studies indexed in international databases (ISI Web of Science) $(6,11)$.

An analysis of the scientific production in the field of Dentistry reveals a significant contribution by researchers with CNPq productivity grants with regard to the publication of scientific articles. There are

Table 3. Distribution of holders of CNPq productivity grants according to institutional affiliation.

\begin{tabular}{|c|c|}
\hline $\begin{array}{l}\text { Affiliatec } \\
\text { grant holde }\end{array}$ & $\begin{array}{l}\text { Affiliated research } \\
\text { grant holders [n }(\%)]\end{array}$ \\
\hline \multicolumn{2}{|l|}{ Public Institutions } \\
\hline \multicolumn{2}{|l|}{ State of São Paulo } \\
\hline University of São Paulo & $43(29.8)$ \\
\hline State University of Campinas & $37(25.6)$ \\
\hline São Paulo State University & $20(13.8)$ \\
\hline \multicolumn{2}{|l|}{ Other States } \\
\hline State University of Ponta Grossa & $2(1.4)$ \\
\hline State University of Pernambuco & $3(2.1)$ \\
\hline State University of Montes Claros & $1(0.7)$ \\
\hline Federal University of Bahia & $1(0.7)$ \\
\hline Fluminense Federal University & $1(0.7)$ \\
\hline Federal University of Minas Gerais & $4(2.8)$ \\
\hline Federal University of Pelotas & $2(1.4)$ \\
\hline Federal University of Santa Catarina & $2(1.4)$ \\
\hline Federal University of Santa Maria & $1(0.7)$ \\
\hline Federal University of Uberlândia & $2(1.4)$ \\
\hline Federal University of Pará & $1(0.7)$ \\
\hline Federal University of Rio de Janeiro & $3(2.1)$ \\
\hline Federal University of Rio Grande do Norte & $3(2.1)$ \\
\hline Federal University of Rio Grande do Sul & $4(2.8)$ \\
\hline \multicolumn{2}{|l|}{ Private Institutions } \\
\hline \multicolumn{2}{|l|}{ State of São Paulo } \\
\hline University of Ribeirão Preto & $1(0.7)$ \\
\hline University of Taubaté & $1(0.7)$ \\
\hline São Leopoldo Mandic Dental Research Center & $3(2.1)$ \\
\hline University of Guarulhos & $3(2.1)$ \\
\hline \multicolumn{2}{|l|}{ Other States } \\
\hline Pontifical Catholic University of Rio G. do Sul & $2(1.4)$ \\
\hline Bahia Foundation for Science Development & $1(0.7)$ \\
\hline University of Passo Fundo & $1(0.7)$ \\
\hline Estácio de Sá University & $2(1.4)$ \\
\hline Total & $44(100.0)$ \\
\hline
\end{tabular}


differences between the research categories and sublevels. The average number of full-text articles published in scientific journals varies according to the category. The groups of researchers in Category 2 produced $38.0 \%$ of the full-text articles, whereas the production of Category 1 researchers was $60.8 \%$.

This suggests that production in each of the categories and sublevels is influenced by the average time in the profession and dedication to scientific research, which is lower among Category 2 researchers. This category is known to be less competitive, as classification is determined considering the number of published articles and the qualification of the journals in which they are published. Therefore, the chances are greater for a young researcher to be placed in this research grant group (12).

It is interesting to note the presence of both genders in research activities, with a predominance of the male gender. Women are concentrated among Category 2 researchers, which suggests their more recent entrance into the scientific granting process.

There is a growing awareness that decisions regarding governmental policies and actions should be grounded on scientific evidence, given their complexity and multiple implications. Consequently, there has been an increasing participation of the government as a promoter, financer and executer of scientific/ technological development policies and activities (1). This situation began at the end of the last century, thanks to the action of the CNPq and CAPES researchers (7). In this context, most research grant holders in the field of Dentistry develop their activities at public institutions. A previous study found that $77 \%$ of researchers in collective healthcare develop their activities at public institutions. This stresses the important role the government plays as an articulator and stimulator of scientific research (12).

For decades, there have been disparities in the development between the large Brazilian macro-regions, which are also expressed in the regional distribution of scientific and technological resources as well as in the regional formation of human resources and knowledge production. The technical-scientific base in Brazil is much more pronounced in the southeast and south regions, to which most of the government investments in science and technology are directed. Indicators reveal that the southeast region houses a large portion of the university centers with a level of excellence in innumer- ous fields of knowledge as well as the most wellequipped research institutes in the country (13).

The present study demonstrates the concentration of researchers in the southeast region, especially in the state of São Paulo. Acknowledgement should be given to the scientific community of this state and to the São Paulo State Research Foundation (FAPESP), which have undertaken important initiatives in broadening the visibility of Brazilian scientific production.

Regarding the field of Dentistry, 65 (72\%) of the 90 postgraduate programs and courses in the country are located in the southeast region (52 in the state of São Paulo), whereas $10(11 \%)$ are located in the southern region, $13(15 \%)$ are located in the northeast region, 1 $(1 \%)$ is located in the northern region and $1(1 \%)$ is located in the middle-west region (8). This fact shows that the formation of researchers and knowledge production on a regional scale follows the same pattern of disparity as seen in the development of the country. Technical-scientific activities are distributed in a heterogeneous fashion throughout the physical space, accompanying the accumulation of capital (13). However, this phenomenon of research concentration is not exclusively Brazilian in nature. In the United States, about $36 \%$ of the scientific production indexed on the databases of the ISI Web of Science in 1998 originated from 4 American states: California, New York, New Jersey and Massachusetts (14).

The present study has limitations regarding the information gathered. The first refers to the quality of information available on the Lattes curricula vitae of the researchers. As the Lattes curriculum vitae is one of the elements employed in judging applications for productivity grants, it is considered an adequate source for the analysis of researcher profiles.

Since the establishement of excellence parameters and information regarding the quality in science currently made available on the internet to the scientific community, an effort has been made by Brazilian professionals to attain certain goals and this is reflected in the growth and improvement of the Brazilian scientific production (7).

Another issue regarding the possibility of overestimating the totality of scientific production is the form of analysis. Articles often have more than one author and two or more authors may be grant holders. In such cases, however, the researchers are frequently classified in different categories and sublevels, which would tend to attenuate the double or triple count of grant holders 
within a category and sublevel.

The present study addressed the profile and distribution of researchers in the field of Dentistry who receive $\mathrm{CNPq}$ productivity grants and emphasized the imbalance of the technical-scientific production among the regions in Brazil. It is the government responsibility to establish policies with the aim of improving its instruments and actions in an effort to diminish the current inequality. The commitment to combating inequality and increasing the standards of balance, especially in the healthcare field, should be the basic premise of the National Science, Technology and Information Policy of the country.

\section{RESUMO}

Este estudo teve como objetivo verificar o perfil dos pesquisadores de Odontologia, bolsistas de produtividade em pesquisa, do Conselho Nacional de Desenvolvimento e Pesquisa (CNPq). A coleta dos dados foi realizada em março de 2008, a partir da base de dados do curriculum vitae (Plataforma Lattes). Observou-se que estavam registrados 144 pesquisadores vinculados a 25 instituições brasileiras de ensino e pesquisa. Esses pesquisadores publicaram um total de 12.997 artigos completos, sendo 6.927 produzidos nos últimos 5 anos. Os bolsistas da categoria 1 ( $\mathrm{n}=77$ ) foram responsáveis por $53,5 \%$ dessa produção, os da categoria $2(n=65)$ por $45,1 \%$ e os bolsistas seniores $(n=2)$ por 1,4\%. Em relação ao vínculo institucional, $90,3 \%$ dos pesquisadores bolsistas desenvolvem suas atividades em instituições públicas e 9,7\% em instituições privadas. Observouse ainda que $84,0 \%$ dos pesquisadores estão vinculados a instituições localizadas na região sudeste do Brasil, sendo que do total dos pesquisadores, 75,0\% atuam no Estado de São Paulo. Este estudo demonstrou a importante contribuição dos bolsistas para a produção científica da área. Ademais, possibilitou o mapeamento da distribuição desses pesquisadores, evidenciando a concentração dos mesmos na região sudeste do país, especialmente no Estado de São Paulo.

\section{REFERENCES}

1. Barreto ML. Scientific and technological knowledge as evidence for policies and regulatory activities in health. Cienc Saúde Colet 2004;9:329-338.

2. Rocha EMP, Ferreira MAT. Indicators of science, technology and innovation: measurement of STel systems in the Brazilian states. Ci Inf 2004;33:61-68.
3. Pinheiro-Machado R, Oliveira PL. The Brazilian investment in science and technology. Braz J Med Biol Res 2001;34:15211530 .

4. Barreto ML. Growth and trends in scientific production in epidemiology in Brazil. Rev Saúde Pública 2006;40:79-85.

5. Perez JF. Research: the construction of new paradigms (Pesquisa: a construção de novos paradigmas). São Paulo Perspec 2002;16:30-35.

6. Guimarães JA. Medical and biomedical research in Brazil. A comparison of Brazilian and international scientific performance. Cienc Saúde Colet 2004;9:303-327.

7. Cury J. The evolution of dental research in Brazil. Braz Oral Res 2004;18:0.

8. Oliveira Filho RS, Hochman B, Nahas FX, Ferreira LM. Financing of the scientific publication and protection of the scientific knowledge. Acta Cir Bras 2005;20:35-39.

9. Brazil Brazilian National Research and Development Council - CNPq 2008 (Brasil. Conselho Nacional de Desenvolvimento Científico e Tecnológico - CNPq 2008). Available at URL: http://www.cnpq.br/index.htm (Latest access: June 20, 2008).

10. Pécora JD. Our English-language journals. Braz Oral Res 2005;19:0-0.

11. Meneghini R. Evaluation of the scientific production and the SciELO Project. Ci Inf 1998;27:219-20.

12. Barata RB, Goldbaum M. A profile of researchers in public health with productivity grants from Brazilian National Research Council (CNPq). Cad Saúde Pública 2003;19:18631876.

13. Barros FAF. The regional unbalances of the technical-scientific production (Os desequilíbrios regional da produção técnico-científica). São Paulo Perspec 2000; 14:12-19.

14. The São Paulo State Research Foundation - FAPESP. Indicators of Science and Technology in the State of São Paulo, 2001 (Fundação de Amparo à Pesquisa do Estado de São Paulo. Indicadores de Ciência e Tecnologia no Estado de São Paulo, 2001) Available at URL: http://www.fapesp.br/ indet/index.htm (Latest access: June 20, 2008).

Accepted July 21, 2008 